JELENA B. BABIĆ-ANTIĆ

DRAGANA M. SPASIĆ ${ }^{1}$

UNIVERSITY OF PRIŠTINA WITH TEMPORARY HEAD OFFICE

IN KosovsKa Mitrovica, FACULTY OF PHILOSOPHY

DEPARTMENT OF ENGLISH LANGUAGE AND LITERATURE

\title{
COUNTERFACTUAL REASONING AND CONCEPTUAL BLENDING IN POLITICAL DISCOURSE
}

ABSTRACT. Conceptual integration and blending are deeply embedded within the human cognition. They are a part of everyday life common for infants and adults alike. Without these fundamental cognitive operations there would be no advancement in any of the aspects of human progress. One small part, a product of these mental operations is "counterfactual reasoning". This ability of human beings to "undo" reality is remarkable and pervasive in every aspect of life.

The ability to operate with the unreal by producing counterfactuals has been a subject of many research projects. Our goal in this paper is to examine the frequency of their appearance in the political discourse, as well as to establish what exactly their purpose is, once they are present in the political discourse.

KEYWORDS: conceptual integration, blending, counterfactual reasoning, political discourse.

1 bebbica2002@yahoo.com; aidnimspasic@yahoo.com

This paper was submitted on August 21, 2017 and accepted for publication at the meeting of the Editorial Board held on September 19, 2017. 
Following Fauconnier and Turner's (1985) theory of mental spaces and conceptual integration network, some more light was shed on the constitutive and governing principles of conceptual blending. It is quite remarkable that blending has received so little attention, considering that it is a fundamental cognitive operation employed in a variety of domains such as: analogy, metaphor, grammatical structures, rhetoric, language and invention of counterfactuals, subject matters like politics, economics, physics etc.

According to Fauconnier and Turner $(2002$, p. 18) "conceptual blending is an invisible, unconscious activity involved in every aspect of human life". In spite of the fact that many cognitive scientists took blends to be exotic and even marginal manifestations of meaning, Fauconnier and Turner proved that in fact it is a central process, uniform, present at all levels of thought, from those simplest to the highest level scientific thoughts. It is a basic mental operation which is crucial for even the simplest kind of thoughts. Its characteristics are speed and invisibility. Having in mind that these mechanisms are formed early in life of each individual and are common for children and adults, it could be the explanation of such crucial activity being scientifically neglected, especially in linguistics.

Each theory explained from the point of view of cognitive linguistics involves some idealized cognitive model and a corresponding vocabulary (Lakoff, George, 1987). Idealized cognitive models come from four different sources: 1. Filmore's frame semantics, 2. Lakoff and Johnson's theory of metaphor and metonymy, 3. Langacker's cognitive grammar, and 4. Fauconnier's theory of mental spaces. This fourth theory provides an introduction to the process of blending, if we follow Fauconnier's description ${ }^{2}$ that each ICM (idealized cognitive model) structures a mental space, which is a basic constituent for every process of conceptual blending. Mental spaces are conceptual in nature and they are what cognitive model theory uses as possible worlds. Hence they are used as representations of our understanding of hypothetical and fictional situations.

2 Cited in Women, fire and dangerous things (Lakoff, 1987, p. 121). 
Conceptual integration and blending are unique to our species. Human beings are "especially skilled to integrate two different inputs and thus create new emergent structures, all basic constituting parts of conceptual integration network" (Turner and Fauconnier, 2002, p. 27). The result of conceptual integration is development of new tools, technologies, and new ways of thinking, while its goal is the creation of new blends. Building an integration network, no matter how simple or extraordinary the blend is, involves the same procedure. This procedure includes setting up mental spaces (input spaces, generic space, and blended space), projecting material selectively to the blend, forming a new emergent structure, and running various operations in the blend itself (Turner and Fauconnier, 2002, p.44). Blends serve various purposes and functions, some of which are rather abstract, or at least they appear so. Some fantastic and exotic ${ }^{3}$ blends are mentioned by Turner and Fauconnier, but they do emphasize that both the simplest and the most complex kinds of blends are created in the same way and behind their creation lies the same cognitive process.

Clearly, blends can be fantastic or not, and when they are fantastic, they may be quite noticeable. But the truth is that unnoticeable blends are much more common in everyday life. On the other hand, it presents quite a challenge to find a fantastic and immediately apparent blend. When it comes to the connection between blending and counterfactuals, it is crucial to add that there would be no counterfactuals without conceptual blending.

\section{COUNTERFACTUALS AND BLENDING}

Sometimes whole integration networks are counterfactual and the results are exotic and extraordinary counterfactual blends. But, it is also worth mentioning that counterfactuals are not an absolute category and that they depend on the point of view that one takes, that is, "on the space that is used as the viewpoint" (Turner \& Fauconnier, 2002, p.230). Examples like "In France, Watergate would not have harmed Nixon", "If Clinton were the Titanic, the iceberg would sink", and the example called "The Iron Lady and the rust belt" with the hypothetical running of Margaret Thatcher for

3 Terms like fantastic, exotic and extraordinary denoting different kind of blends were used by Turner and Fauconnier (2002) 
president in the United States, are the exquisite examples of counterfactuals. Not only by their fantastic blending process, which is pragmatically anomalous, but also by their linguistic form.

While the examples mentioned above are fantastic, there are those which are common and almost unnoticeable. Counterfactual reasoning is an everyday event that usually goes unnoticed and unremarked, as in the cases like: "If John had come, Bill would have left". ${ }^{4}$ Examples of this kind belong to unreal past conditionals and F. R. Palmer (Palmer, 2001) suggests that it is wrong to consider them all counterfactual, although the majority of them are.

Basically, counterfactuals are sentences of a type:

\section{1) "If I were you, I would quit."}

In the English language a typical form of counterfactual involves two clauses: the antecedent clause with if, also known as the protasis and the consequent clause, called apodosis. Of course, they may appear in either order. The same conventional forms are used in grammar when it comes to formation of counterfactual blends, whether they are everyday common examples or fantastic and unreal. Counterfactuals include the so called reductio ad absurdum principle, or in other words, proof by contradiction. In linguistics, it refers to the proposition whose falsity we intend to prove by leading the said proposition to its internal contradiction, and thus proving the falsity of the original proposition.

Counterfactual conditionals differ from indicative conditionals by speaker's belief in the falsity of the if-clause or protasis. A combination of tenses, moods and time references is what makes the difference between indicative and counterfactual conditionals. By looking at the following sentence

1) If it were raining, then he would be inside.

what we can notice is that the if-clause is in the past subjunctive of the subjunctive mood, while apodosis is in the conditional mood. The speaker believes that protasis is not true - If it were raining (and it is not raining, so the protasis is not true), while the apodosis may or may not be true, but it would certainly be true in the counterfactual case of if-clause being true.

The usual approach when thinking of counterfactuals is setting up an alternative world, with differences from the real world which

4 Example from F.R. Palmer's Mood and modality (Palmer, 2001, p. 208). 
are specified by linguistic expression; and then looking for its direct consequences. For some, this may sound easy, but in fact, the complexity of counterfactuals lies in their logic. They are considered to present a difficult problem, both logically and semantically.

Turner and Fauconnier define counterfactuality as "forced incompatibility between spaces" and they even offer a narrower definition where "one space has forced incompatibility with respect to a space we take to be actual" (Turner \& Fauconnier, 2002, p. 230). Counterfactuals have a basic and enormous importance in human life. Experts from various disciplines researching counterfactuals and their role in various aspects of life keep pointing to their indispensability in everyday life. In linguistics, this is noticeable by certain structures and lexical forms which very often evoke comparison frames, which are also known as "factuality windowing" (Talmy, 2003, p. 291). This refers to a possibility to make comparison between the given alternatives. The main attention is usually on only one option, but factual / counterfactual pair makes it possible for the other option to be present and act as a foil for comparison in a form of occurrence vs. nonoccurrence of some event.

\section{COUNTERFACTUALS IN POLITICAL DISCOURSE}

Our species has a remarkable capacity for counterfactual reasoning. We are mentally well equipped to operate with the unreal, but none of the mentioned would be possible without our capacity for advanced conceptual integration. When it comes to counterfactuals and their wide usage in various domains of language and social science, it is very important to make clear that the formation of counterfactuals would be impossible without blending. They are the product of conceptual integration. Many researchers claim that counterfactual reasoning is a prerequisite for any form of learning from history. As we have already mentioned, beside many other roles that counterfactual reasoning plays in various scientific domains, one that cannot be neglected is certainly the role it plays in political science and world politics.

Different authors suggest many definitions for counterfactual propositions, so it is useful to clarify that the generic form they take is: "If it had been the case that C (or not C), it would have been the case that E (or not E)." (Fearon, James, 1991, p. 169-195). On the 
other hand, Tetlock and Belkin (Tetlock \& Belkin,1996, p. 4) offer a precise philosophical definition given by Skyrms and proceed by saying that "counterfactuals are subjunctive conditionals in which the antecedent is known or supposed to be known, for the purposes of the argument to be false" (Skyrms, Brian, 1991 in Tetlock and Belkin, 1996, p. 4).

When political scientists and politicians use counterfactuals, they do so explicitly and very carefully. An enormous number of politically consequential arguments is qualified as counterfactual. It could be said that in everyday life counterfactual propositions are simply irresistible, especially after some bad events. The same applies to political discourse, where a number of reasons trigger their production.

Some of the clearest examples emphasized by many experts about the importance of counterfactuals in politics come from the research on causes of World War I. Many authors elaborate on the reasons and factors that caused the beginning of the War. In connection to this, James Fearon adds: "If cause X had not been present, the war either would not have occurred or would have been much less likely to have occurred" (Fearon, 1991, p. 181).

People rely on counterfactual arguments in politics and everyday life in order to grasp the significance of current events. Counterfactuals help people learn from experience and they make possible for emotions like regret, shame, guilt, and blame to come to the surface. Counterfactual thoughts are implicated in various cognitive activities, from daydreams and fantasy, to deduction and probability calculation. Also, counterfactual reasoning is inevitable in any field in which researchers want to draw cause - effect conclusions. Therefore, they are obliged to justify their claims that certain causes produced given effects, and they do so by producing counterfactual examples. In those, they hypothesize about what would have occurred if a certain cause had taken some other direction, thus making a new environment in that possible world, which differs from the actual one that they are trying to explain.

Counterfactuals are usually produced after bad outcomes. According to Ruth Byrne (Byrne, 2002, p. 427), they can be divided into upward and downward counterfactuals, each serving a particular purpose. The results of recent research show that people are prone to generate more upward counterfactuals, that is about how a situation could have turned out better. They are generated 
after bad outcomes or goal failures, and they help people learn from their mistakes:

1) Had we been better prepared, peace might have been preserved. ${ }^{5}$ (FSST)

Another type of counterfactuals is about how a situation could have turned out worse, and they help people to feel better about themselves. They are usually generated when people are in a good mood:

2) If we had not reasoned and fought and won those battles together, many people would have been left behind. ${ }^{6}$ (FSST)

Many researchers are trying to reveal the logic behind the counterfactual thought, but it is not easy to reach the uniform view concerning this rather tricky problem. There is no ideal way of judging the appropriateness of counterfactuals. Researchers treat this problem differently, but it is still possible to name the basic characteristics of the so-called "ideal counterfactual". According to Tetlock and Belkin (1996), those attributes include clarity, logical consistency and cotenability, historical consistency, theoretical consistency, structural consistency, and projectability.

As we have emphasized throughout the paper, the research shows that counterfactuals are very common in political discourse and counterfactual reasoning is a part of everyday life. More than hundred pages of speeches were thoroughly searched for examples of counterfactual reasoning. Examples included here come from the speeches delivered by Barack Obama, Nelson Mandela, Martin Luther King, Ronald Reagan, John F. Kennedy, Eleanor Roosevelt, Princess Diana, and Ann Howard Shaw. It is quite known that a significant number of speeches by famous presidents, politicians, and royalty are usually rich with contemplations of a kind "what might have been" and it makes it very appropriate for the usage of counterfactuals. By using them, politicians and presidents try to explain what exactly influenced a certain course of historical events, justify their decisions which led to some important events, as well as what could have been done differently to change the

5 The example is a sentence by US president Ronald Reagan found in the speech he delivered about National Security in 1983 and is taken from http://www.famous-speeches-and-speech-topics.info/. The abbreviation FSST will be used as a reference hereinafter for all examples used in this paper and available at this website.

6 This example comes from the speech made by Ann Richards in 1988 known as a DNC Keynote Address and is taken from http://www.famous-speeches-andspeech-topics.info/. 
course of history, etc. Therefore, the pages to follow will contain examples of counterfactual reasoning found in the above mentioned political speeches.

In his speech from March 2008 under the heading "A more perfect union", still at the position of a senator, Barack Obama elaborates on his origin, political views, and reasons for running for presidency. Admitting that his campaign is far from perfect, he still expresses true American values and uses this counterfactual: "If I didn't believe with all my heart that this is what the vast majority of Americans want for its country, I would not be running for President" (FSST). It is quite clear that as a presidential candidate he is obliged to believe in the best possible option for the well-being of the country. Therefore, the protasis is false, as well as the apodosis, since he is in the middle of a presidential campaign.

Another example of counterfactual reasoning can be found in the speech by Nelson Mandela. Trying to explain the need for new ways of struggle and fight for the rights of black people, as a part of the so called Defiance Campaign, in his speech from 1953 called "No easy walk to freedom" he mentions as a key goal the need to fight on a higher level with recuperation of strengths. He therefore reminds: "To have gone blindly as if nothing had happened, would have been suicidal and stupid" (FSST). By saying this, he points out that their patience was crucial and the decision to prepare and wait for the right moment was very wise. Any other move would be fatal and counterproductive to their peaceful struggle.

A very interesting example of counterfactual reasoning is included in the 1968 speech of a famous rhetorician Dr. Martin Luther King. He speaks of cruel violation of human rights of the black people in 1968 in America and talks about the incident when he was stabbed in the chest by a woman, while he was autographing his books. He was rushed to hospital and the next day there was a headline in The New York Times: "If I had merely sneezed, I would have died" (FSST). It turned out that the tip of the blade was just a few inches of his aorta, and in case that he had sneezed, he probably would have died. But the truth is that he did not sneeze, and therefore he did not die. Elaborating on how happy he was because he did not sneeze, he mentions all the important dates in the history of struggle for the rights of the black people and continues: "If I had sneezed, I wouldn't have had a chance later that year, in August, to try to tell America about a dream that I had had. I'm so happy that I didn't sneeze."(FSST) 
Another speech by a famous president Ronald Reagan was held in March 1983. The topic was National security, the traditional duty for each president of The United States. Talking about the history we all share, he mentions two world wars, none of them started by the Americans, but in which they were still involved. Talking about decisions that could have been made differently and thus might have changed the course of events, he adds: "Had we been better prepared, peace might have been preserved" (FSST). Reagan explains that they did all in their power to avoid being drawn into each of the wars. But the fact remains that they were badly prepared and therefore couldn't prevent any of them. Later on in his speech, Reagan uses another counterfactual talking about arms control negotiations with the Soviets. He adds how they managed to persuade the Russians to sit at the negotiating table and uses this counterfactual: "If there weren't our planned deployments, they wouldn't be there" (FSST) Therefore, he justifies their efforts which brought the Soviets to accept their offer to negotiate, and explains that without their wise moves, the situation would have probably taken another direction.

John F. Kennedy made a speech in 1963 called "Above ground nuclear testing". Talking about relations between America and Russia, the heritage of the Second World War, Cold War and how it affects all the countries, JFK continues by saying: "We must deal with the world as it is, and not as it might have been had the history of the last 18 years been different" (FSST). The fact is that history is not different; the world is as it is and everything else would be contrary to facts.

The following speech by Eleanor Roosevelt was held in 1936 at the Columbia Library Association Diner. She emphasizes the importance of libraries to people and the necessity for each state in America to have them. Unfortunately, she explains, the situation is quite different and people are deprived of them and other social and cultural events. She adds: "If I had to work six hours a day, I would not know what to do myself" (FSST). She explains that a hypothetical situation of people having to work fewer hours would not bring them any good. They would not have anything better to do since there are no libraries. The apodosis is quite surprising since more free time should bring more opportunities, and therefore this kind of proposition is not what one would normally expect to hear after the hypothetical working hours made shorter. 
The late Princess Diana has always been known by her humanitarian work and kindness. In 1997 she held a speech about landmines and their terrible aftermath in Angola and other countries at war. She emphasizes that from all the landmines found in war zones and countries that have come out of war, one third has been found in Africa. Their consequences to civilians are tragic and for those who somehow survive their injuries, they are life lasting. She then adds: "Even if the world decides tomorrow to ban these weapons, the terrible legacy of mines would continue to plague the poor nations of the Globe" (FSST). Then she elaborates on it and proceeds by saying that banning mines is quite unlikely to ever happen. Knowing the reality as it is in today's world, we can easily conclude that industrial production of weapons, including mines, will exist as long as there are people. Hypothetically speaking, even if it does happen one day, we would normally expect that the world would then be a better place and that the problem would no longer exist. Therefore, the late Princess Diana used a counterfactual to state her opinion and describe the horrible consequences of mines ever produced.

Ann Howard Shaw, a proclaimed republican, in 1915 talks of the importance that women should be given the right to vote. In her speech she explains that the so-called "suffragists" as herself believe in the right of every human to have a voice in the government. Then she quotes an "anti-suffragist" view which opposes to the request that women should have a right to vote with these words: "If they did have it, they would not use it" (FSST). This claim sounds rather strange, especially if we consider how persistent and hard the efforts of women to finally receive the right to vote were. But in 1915 there was a number of anti-suffragists fighting against women's right to vote, under the claim that even then, they would vote exactly as their husbands. Another interesting counterfactual explaining this view is the following: "Even if we have no husbands, that would not affect the result because we would vote just as our husbands (which we do not have) would vote if we had one" (FSST). This counterfactual is obviously fantastic by its logic and a good enough proof that counterfactuals present a powerful tool in political discourse, used by most politicians to convey various political messages.

CONCLUSION Turner and Fauconnier were the first to reveal the truth that lies behind the fundamental cognitive activity known as conceptual 
blending and present a theory of mental spaces. They were the first to ask the question how it was possible that such fundamental cognitive operation as conceptual blending, common for infants and adults alike, had stayed unrecognized for so long. Their theory finally brought the long expected answers to many scientific questions in domains like psychology, logic, analogy, metaphor, linguistics etc.

Considering everything previously said and paying attention to counterfactual examples we have shown as a piece of a very rich political corpora, it is clear that in the real world it is not possible to "rerun the tape of history" (Tetlock and Belkin,1996, p.37). But at the same time, considering numerous examples of counterfactual thoughts used in world politics, they present suggestive evidence that as a rhetorical tool they are very tempting. As soon as a politician or a leader of a country wants to justify his/hers plans for something they intend to do or have already done, counterfactuals are available as the best possible choice. connect the incompatible domains has been scientifically proven. Undoing the reality and counterfactual reasoning is an integral part of our everyday thinking. We are surrounded by blends, simple and unnoticeable and fantastic alike, from newspaper headlines and television commercials, to political debates and campaigns.

Politicians produce a significant number of counterfactual propositions in their political speeches. By using them they can justify or criticize decisions which led to particular course of events, express their regret in connection to goal failures, or satisfaction due to important accomplishments.

As many scientists have already emphasized, the nature of counterfactuals is quite intricate and depends on the viewpoint that one takes. Sometimes they are obvious and noticeable, but there are also examples that are quite confusing. In order to point out how important it is to take considerable efforts in the study of counterfactuals, Turner and Fauconnier (2002, p. 31) quote the philosopher Nelson Goodman: "The analysis of counterfactual conditionals is no fuzzy little grammatical exercise. Indeed, if we lack the means for interpreting counterfactual conditionals, we can hardly claim to have any adequate philosophy of science" 
The work of Turner and Fauconnier resulted in a theory about mental spaces and consequently brought the long awaited answers about the nature of conceptual integration. Many scientific disciplines such as psychology, logic and linguistics, have benefitted from their theory and have found answers to many scientific questions in these fields. The examples of counterfactual thinking that we have considered in this paper, all point to the conclusion about their importance and indispensability in politics and rhetorics alike. This becomes particularly clear when it comes to decisons made by politicians and leaders which strongly influenced and led to some major historical events. Since turning back the time is not an option, counterfactuals are a very effective tool for the justification of their earlier decisions.

The problems counterfactuals pose are common and important to philosophers, linguists, politicians, sociologists and other social scientists. Counterfactual thinking seems to be everywhere around us and its nature and intricacy will continue to intrigue us in the future, as well as remain an important subject of scientific study.

REFERENCES Byrne, R. (2002). Mental models and counterfactual thoughts about what might have been. Trends in Cognitive Sciences, Vol. 6, №10, 426-431.

Fauconnier, G. and Turner, M. (2002). The way we think. Conceptual blending and the mind's hidden complexities. New York: Basic books.

Fearon, D. J. (1991). Counterfactuals and hypothesis testing in political science. World Politics, Vol. 43, № 2,169-195.

Lakoff, G. (1987). Women, Fire, and Dangerous Things. What categories reveal about the mind. Chicago and London: The University of Chicago Press.

Palmer, F.R. (2001). Mood and modality. Cambridge: Cambridge University Press.

Skyrms, B. (1991). Carnapian inductive logic for Markov chains. Erkenntnis, 35, 439-460.

Talmy, L. (2003). Toward a cognitive semantics. London and Cambridge: Massachusetts Institute of Technology.

Tetlock, E.P. and Belkin, A. (1996). Counterfactual thought experiments in world politics: logical, methodological and psychological perspectives. Princeton, New Jersey: Princeton University Press.

Famous Speeches and Speech Topics. www.famous-speeches-and-speechtopics.info 
ЈЕЛЕНА Б. БАБИЋ АНТИЋ

ДРАГАНА М. СПАСИЋ

УНИВЕРЗИТЕТ У ПРИШТИНИ СА ПРИВРЕМЕНИМ СЕДИШТЕМ

У КОСОВСКОЈ МИТРОВИЦИ, ФИЛОЗОФСКИ ФАКУЛТЕТ

КАТЕДРА ЗА ЕНГЛЕСКИ ЈЕЗИК И КЬИЖЕВНОСТ

РЕЗИМЕ

\author{
КОНТРАФАКТУАЛНО РАСУЂИВАЮЕ \\ И ПОЈМОВНА ИНТЕГРАЦИЈА У ПОЛИТИЧКОМ ДИСКУРСУ
}

Људска способност за конструисање нереалног и повезивање неспојивих појмова научно је доказана. Анулирање реалности и контрафактуално закључивање представљају део нашег свакодневног размишљања. Окружени смо брендовима, простим и неприметним, као и фантастичним, почевши од наслова у новинама и телевизијским рекламама, до политичких кампања и дебата.

Политичари производе знатан број контрафактуалних исказа у својим политичким говорима. Користећи њих, они могу оправдати или критиковати одлуке које су резултирале одређеним догађајима, могу исказати своје жаљење у вези са неоствареним циљевима или задовољство услед важних постигнућа.

Као што су многи научници истакли, природа контрафактуала је прилично нејасна и условљена је становиштем с којег се посматра. Некада је реч о контрафактуалима који су очигледни и приметни, али постоје и прилично збуњујући примери контрафактуала. Како би истакли значај улагања у истраживање контрафактуала, Тарнер и Фоконије (2002) цитирају филозофа Нелсона Гудмана: „Истраживање контрафактуала није нејасна граматичка вежбица. Уколико нам недостају средства за тумачење контрафактуалних кондиционала, тешко је тврдити да заправо постоји адекватна филозофија науке.“

Рад Тарнера и Фоконијеа резултирао је теоријом о менталним просторима и стога понудио дуго очекиване одговоре о природи појмовне интеграције. Многе научне дисциплине попут психологије, логике и лингвистике, имале су користи од њихове теорије и пронашле су одговоре на многа научна питања у овим областима. Примери контрафактуалног расуђивања које смо представили у овом раду, сви упућују на закључак о њиховом значају и неопходности у политици и реторици. То постаје јасно када је реч о одлукама политичара и лидера које су знатно утицале и довеле до важних историјских догађаја. Пошто враћање 
време уназад није могуће, контрафактуали представљају веома ефикасно оруђе за оправдање одлука из прошлости.

Проблем који представљају контрафактуали заједнички је и важан филозофима, лингвистима, политичарима, социолозима и другим научницима. Изгледа да је контрафактуално размишљање свуда око нас те ће нас његова природа и заплетеност интригирати и убудуће и остати важно питање научних истраживања.

КљУчнЕ РЕчи: концептуална интеграција, интегрисање, контрафактуално размишљање, политички дискурс.

Овај чланак је објављен и дистрибуира се под лиценцом Creative Commons Ауторство-Некомерцијално Међународна 4.0 (СС BY-NC 4.0 |

https://creativecommons.org/licenses/by-nc/4.0/).

This paper is published and distributed under the terms and conditions of the Creative Commons Attribution-NonCommercial International 4.0 licence (CC BY-NC 4.0 | https://creativecommons.org/licenses/by-nc/4.0/). 